\title{
ばせどう氏病，甲狀腺中毒症(狹義)及ビ單純 性甲狀腺腫ノ組織呼吸ニツイテ
}

\author{
東北大學醫學部桂外科教室專攻生 \\ 大阪大學附均醫學專門部醫學士
}

後藤昇 本

\section{Tissue Respiration of Thyroidgland Obtaind from Exophthalmic Goiter, Toxic Goiter and Simple Goiter.}

By

\author{
S. Goto. \\ Tohoku University Katsura-Geka.
}

The number of these diseases which I could study was twentoy in all. Ten of them exophthalmic goiter, seven of them toxic goiter, simple goiter was one, and nodural goiter was two. About ncdural goiti I measured normal tissue for the control.

As for respiration rate $\left(\mathrm{Q}_{\mathrm{O}}\right)$ exophthalmic goiter and also toxic goiter are high, simple goiter and the control are low, Sinple goiter is equal normal tissure, but I can't say every time exophthalmic goiter is higher than that of toxic goiter, hecause some of toxic goiter is higher than that of exophthalmic goiter.

So that I maje up a respitation type for example and found at all time the oxygen consumption was very variable about thyroidtissue. In respect of this respiration type I could differ exophthalmic goiter from toxic goiter clearly.

Apparatus Barcraft, medium phosphate solution, slice of thyroidgland about $80 \mathrm{mg}$ drying weight are used and measured accuarately the difference of the manometer which occured during five minutes.

I found following phenomena:

1) At the first period of respiration tyle the consumption of exophthalmic goiter is lower and after regular interval becomes higher consumption, and on the cortrary toxic goiter at first liigher and falls down quickly. Simple goiter and two normal tissue are not so variable, slowly fall down.

2) By the microscopic observation of the epitheliums, when it is hyperplasia, the respiration raie is high and hypoplasia low. And when follicle containes a plenty of colloid droplets the consumption is also high, howover the opitheliums is not hyperplasia.

3) Determination of the respiration rate is connected with relation ketween the amount of medium and tissue.

4) By addition of inorganic iodide the follicle cannot make thyroglobulin in 
the epitheliums, but iodide does not disturo to make up thyroxin from the thyreoglobulin, colloid dropleis which was stored in the follicle, and I think it is true that surviving thyroidtissue is always stimulating itself by its own secretory function.

5) There is no relation between tissue respiration of the thyroidgrand and basal metabolism rate.

第1章 緒 㝘。

第 2 章 䨢驗方法

第 3 章 筫驗成續

第 1 節 各症例症狀卜曲線

第 2 節 呼吸型ニツィテ
E

\section{次}

\section{第4算 淁 案}

第 5 草 總 括

第6 算 結 諭

附 主要文豍

\section{第 1 䆞 緒䨐}

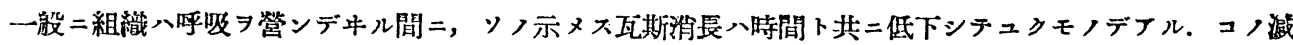

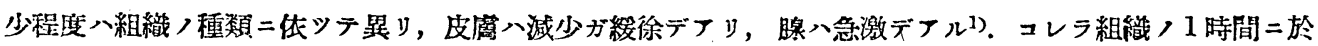

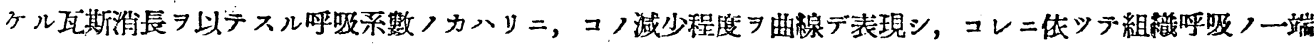
ヨ知ルコトガ出來ル。

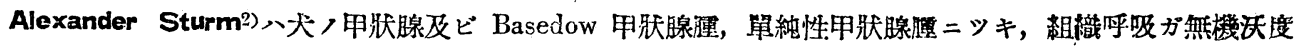
デ如何二變化スルカ, 10分間二示メス瓦斯消長 シ以テ曲線シ作ツタ。

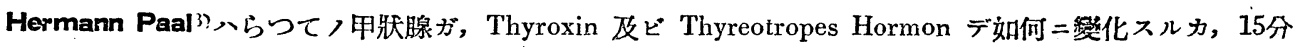
每工觀察シタ.

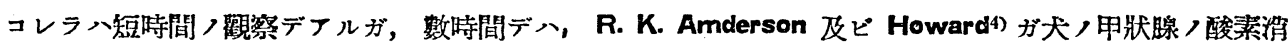

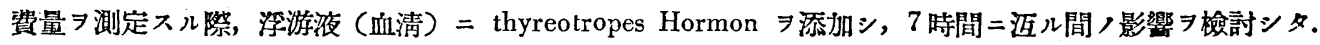
(Warburg /裝置).

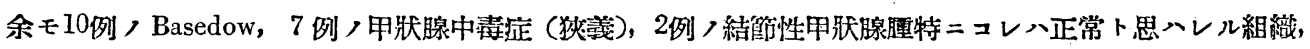

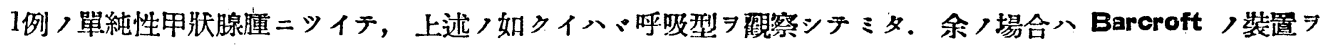

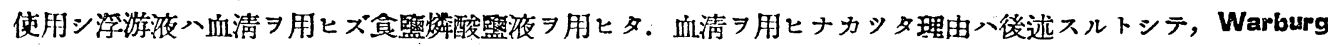

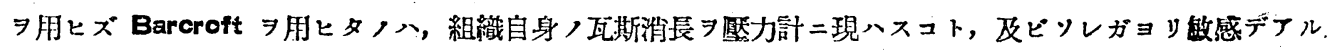
コト,ソノタメ5分每二筧祭スルコトガ出來タカラデフル。

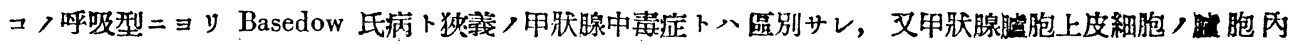
Hormon 分泌, 盛胞外游出二關シデー端ヨ究明シタト信ズル。

\section{第 2 章 驗 方 法}

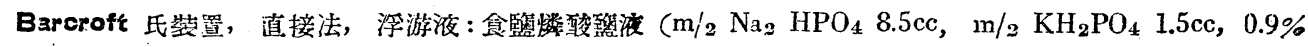

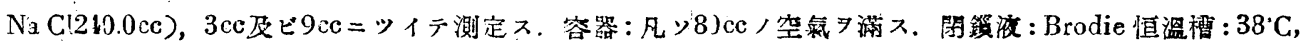
振動數每分90回.

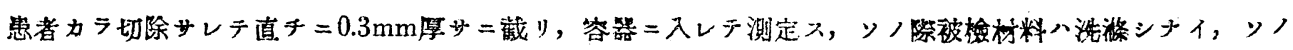

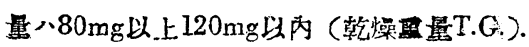

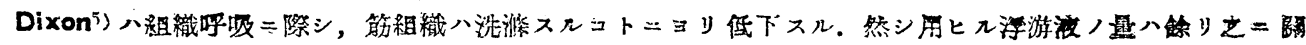

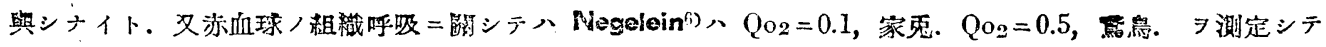

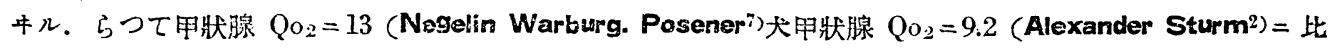
シテ僅少ナルコトガ首显サレル，又用狀腺粗織中二含有サレル赤血球八微量デアル。

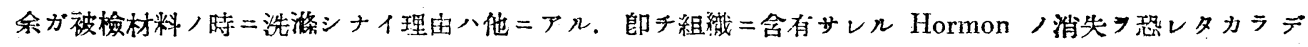


$ア \Re$.

容器恒數ハMüntzer-Neumann 氏法ニョッテ算出シタ。患者ハ總テ術前めちおぢーるョ眼用シテ手術適 㒣トシタ.

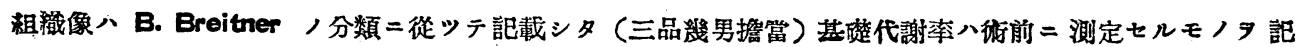
載シタ(木村政一匴䈏).

第 3 章 害 驗 成 績

第 1 飾各症例了症狀卜曲線

Tabelle 1

Basedow 鈴O清O門 30歲 今

Str. diff. coll. basedowifiata $\begin{cases}\text { Follikel ノ大サ } & \text { 中 } \\ \text { Colloid ノ含有程度 } & \text { 土 } \\ \text { 腿胞上皮細胞增殖程度 } & +\end{cases}$
Tabelle 欲明

Qo2：乾燥組種重量 $1 \mathrm{mg}$ ガ 1 時間 $=00^{\circ} \mathrm{Cl}$ 莱 壓ノ下二消䨘シタ

酸素量

T.G. : 乾燥租樴重量

中 甲, 乙, 丙: 容器/名稱

土 B.M.R. : 基礎代謝索

+

Graef $(+)$ Tachycardie $\quad 130 / \mathrm{M}$

\begin{tabular}{|c|c|c|c|c|c|}
\hline & \multicolumn{2}{|c|}{$\begin{array}{l}\text { T.G. } 80 \mathrm{mg} \\
\text { 浮游液 } 5 \mathrm{cc}\end{array}$} & \multicolumn{2}{|c|}{$\begin{array}{ll}\text { 乙 } & \begin{array}{l}\text { T.G. } 72 \mathrm{mg} \\
\text { 浮游液 } 5 \mathrm{cc}\end{array} \\
\end{array}$} \\
\hline 時 & 間 & 傿 & 美 & 皉 & 差 \\
\hline \multicolumn{2}{|c|}{$3^{15} \mathrm{uhr}$} & 7 & & 8 & \\
\hline \multicolumn{2}{|c|}{325} & 9 & & 16(最大) & \\
\hline \multicolumn{2}{|l|}{335} & 19 & & 14 & \\
\hline \multicolumn{2}{|l|}{$3^{45}$} & 20 (最大) & & 13 & \\
\hline \multicolumn{2}{|l|}{355} & 14 & & 16 & \\
\hline \multirow{2}{*}{\multicolumn{2}{|c|}{45}} & 15 & & 13 & \\
\hline & & $+\longdiv { 8 4 } \ldots \ldots$ & $\mathrm{o}_{2} \quad 5.25$ & +281 . & $\ldots \ldots \ldots \ldots . . . .55$ \\
\hline \multicolumn{2}{|l|}{415} & 16 & & 16 & \\
\hline \multicolumn{2}{|l|}{425} & 12 & & 13 & \\
\hline \multicolumn{2}{|l|}{485} & 19 & & 16 & \\
\hline \multicolumn{2}{|l|}{445} & 18 & & 16 & \\
\hline \multicolumn{2}{|l|}{455} & 15 & & 12 & \\
\hline \multirow{2}{*}{\multicolumn{2}{|c|}{55}} & 14 & & 13 & \\
\hline & & $87 \cdots \cdots$ & & $85 \cdots$ & $\ldots \ldots \ldots \ldots \ldots \ldots . .90$ \\
\hline \multicolumn{2}{|l|}{515} & 16 & & 16 & \\
\hline \multicolumn{2}{|l|}{525} & 16 & & 13 & \\
\hline \multicolumn{2}{|l|}{$5^{35}$} & 13 & & 13 & \\
\hline \multicolumn{2}{|l|}{545} & 17 & & 15 & \\
\hline \multicolumn{2}{|l|}{$5^{55}$} & 13 & & 13 & \\
\hline \multirow{2}{*}{\multicolumn{2}{|c|}{65}} & 13 & & 12 & \\
\hline & & $76 \cdots \cdots$ & $\cdots . .75$ & $81 \cdots$ & ...............5.55 \\
\hline
\end{tabular}

Tabelle 2

Basedow 佐O 更O 红裁 우

Str. diffusa Paernehymatosa basedowiana

B. M. R. +21.29

hühnereigro $\beta$

$\begin{array}{lc}\text { Follikel } & \text { ( } \\ \text { Colloid } & (-) \\ \text { 上皮細胞 } & \text { H }\end{array}$

眼球突出 $(+) \quad$ Möbius $(t) \quad$ Graefe $(t) \quad$ Dalrymple $(t) \quad$ Glanzauge $(t)$

Tachycardie 120/M 


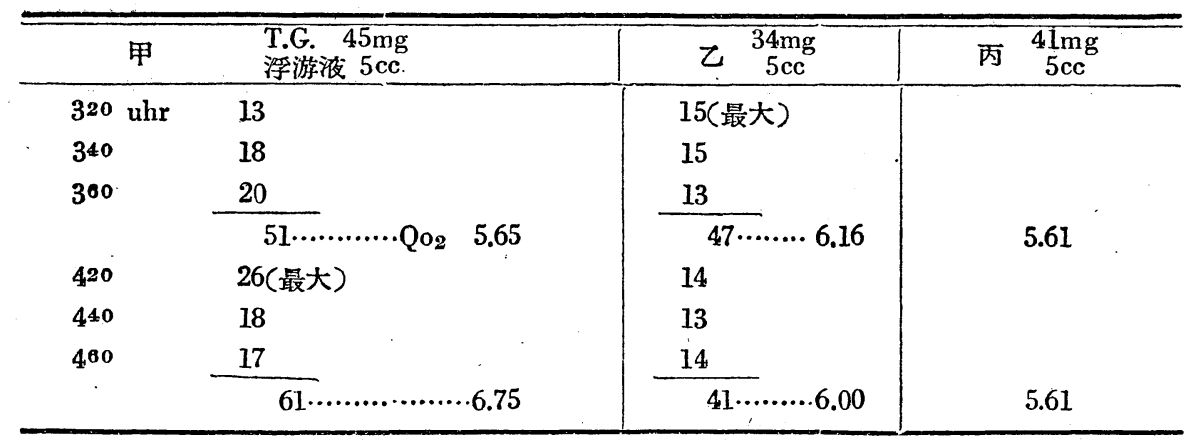

Tabelle 3

Basedow 10 42糮 우

B. M. R. + 23. 31 Gänseeigro $\beta$

Glanzauge( + ) Tachycardie $128 / \mathrm{M}$
Str. diff. parench. basedowiana $\begin{cases}\text { Follikel } & \text { 小 } \\ \text { Kolloid } & - \\ \text { 上皮細胞 }\end{cases}$ 眼球突出 $(t)$ Dalrymple $(t)$ Möbius $(t)$,

\begin{tabular}{|c|c|c|c|}
\hline & $\begin{array}{c}75 \mathrm{mg} \\
5 \mathrm{cc}\end{array}$ & 乙 $\begin{array}{c}31 \mathrm{mg} \\
5 \mathrm{ce}\end{array}$ & 丙 $\begin{array}{r}67 \mathrm{mg} \\
5 \mathrm{cc}\end{array}$ \\
\hline $220 \mathrm{uhr}$ & 33 & 12 & - \\
\hline $2^{40}$ & 38 & 14 & - \\
\hline \multirow[t]{2}{*}{30} & 41 & 17(最犬) & - \\
\hline & $112 \cdots \cdots \cdots . . . Q_{02} \quad 6.75$ & $43 \cdots \cdots . .6 .94$ & $91 \cdots \cdots \cdots .6 .89$ \\
\hline 320 & 32 & 11 & - \\
\hline $3^{40}$ & 43 & 14 & - \\
\hline \multirow[t]{2}{*}{40} & 49 (最大) & 12 & - \\
\hline & $\overline{123}$ & 37 & 92 \\
\hline 420 & 17 & 13 & - \\
\hline- & - & - & - \\
\hline- & - & - & - \\
\hline & $\overline{111}$ & 34 & $\overline{94}$ \\
\hline
\end{tabular}

Tabelle 4

Basedow 村O きO 우 B.M.R. + 43.99 hühnereigro $\beta$ 眼球突出(左) $(+) \operatorname{Graefe}(t)$

Dalrymple( $(t)$ Glanzauge( $(t)$ Tachycardie 113/M

\begin{tabular}{|c|c|c|c|c|}
\hline & $\begin{array}{c}68 \mathrm{mg} \\
3 \mathrm{cc}\end{array}$ & $\begin{array}{l}56 \mathrm{mg} \\
9 \mathrm{cc}\end{array}$ & 丙 & $\begin{array}{r}56 \mathrm{mg} \\
6 \mathrm{cc}\end{array}$ \\
\hline $2^{10} \mathrm{uhr}$ & 7 & 14(最大) & - & \\
\hline 220 & 12 & 11 & - & \\
\hline $2^{30}$ & 13 & 13 & - & \\
\hline $2^{40}$ & 15 (最大) & 10 & - & \\
\hline 250 & 8 & 11 & - & \\
\hline \multirow[t]{2}{*}{30} & 11 & 12 & \multicolumn{2}{|l|}{ - } \\
\hline & $66 Q_{02} \ldots \ldots \ldots \ldots \ldots .9 .95$ & $71 \cdots \cdots .6 .21$ & \multicolumn{2}{|c|}{$74 \ldots \ldots .6 .61$} \\
\hline 310 & 12 & 9 & & \\
\hline $3^{20}$ & 13 & 12 & & \\
\hline
\end{tabular}

Tabelle 5 


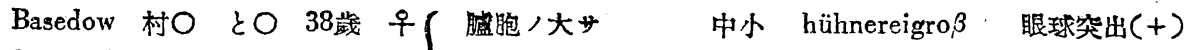

Str. diff. foll. basedowifita $\{$ Colloid / 量 - Glanzauge $(+)$ Uberwimpern $(+$ B. M. R. + 46.65 (腿胞上皮細胞堦殖 \pm Tachycardie 128/M

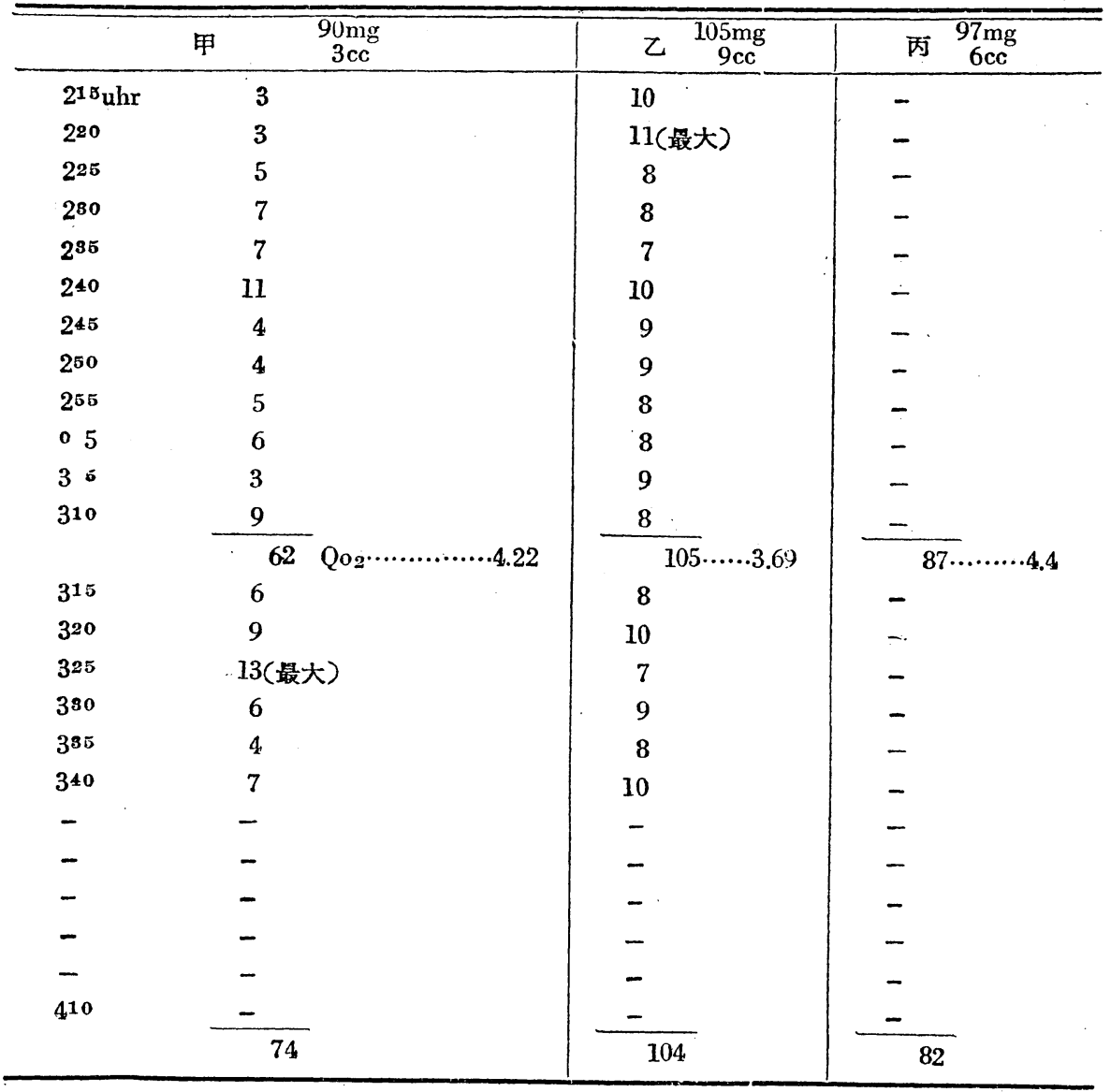

\section{Tabelle 6}

Basedow $\mathrm{O}$ 우 $\quad$ B. M. R + 17. 92 hühnereigro $\beta$ 眼球突出 $(-)$

Dalrymple( + Glanzauge( $(+) \quad 15 / \mathbb{X}^{\prime} 48^{\circ} \rightarrow 21 / \mathbf{I}^{\prime} 49(-) \quad$ Uberwimpern( $(+)$ ，眼奖異裳 (t) Tachycardie $111 / \mathrm{M}$

\begin{tabular}{|c|c|c|c|}
\hline & $\begin{array}{c}66 \mathrm{mg} \\
3 \mathrm{cc}\end{array}$ & 乙 & $\begin{array}{r}72 \mathrm{mg} \\
9 \mathrm{cc} \\
\end{array}$ \\
\hline $2^{10} u h r$ & 7(最大) & \multicolumn{2}{|l|}{ 8(最大) } \\
\hline 215 & 4 & \multicolumn{2}{|l|}{6} \\
\hline 290 & 6 & \multicolumn{2}{|l|}{5} \\
\hline 225 & 4 & \multicolumn{2}{|l|}{5} \\
\hline 280 & 5 & \multicolumn{2}{|l|}{6} \\
\hline 285 & 5 & \multicolumn{2}{|l|}{4} \\
\hline $2^{40}$ & 5 & \multicolumn{2}{|l|}{4} \\
\hline $2^{4 \bar{v}}$ & $\downarrow$ & \multicolumn{2}{|l|}{5} \\
\hline 250 & 5 & \multicolumn{2}{|l|}{5} \\
\hline $2^{55}$ & 4 & \multicolumn{2}{|l|}{5} \\
\hline
\end{tabular}




\begin{tabular}{|c|c|c|}
\hline 30 & 4 & 4 \\
\hline \multirow{2}{*}{35} & 4 & 4 \\
\hline & 77 Qo2 $\ldots \ldots \ldots \ldots . . . . .32$ & $61 \ldots \ldots \ldots \ldots \ldots . . .23$ \\
\hline 310 & 7 & 6 \\
\hline 315 & 3 & 5 \\
\hline 320 & 5 & 5 \\
\hline 325 & 4 & 4 \\
\hline $3^{30}$ & 4 & 4 \\
\hline $3^{85}$ & 4 & 5 \\
\hline $3^{40}$ & 4 & 4 \\
\hline 345 & 4 & 4 \\
\hline $3^{50}$ & 4 & 4 \\
\hline 355 & 5 & 5 \\
\hline \multirow[t]{2}{*}{40} & 4 & 3 \\
\hline & 52 & 56 \\
\hline
\end{tabular}

Tabelle 7

Basedow 三0みОろ + ․ B. M. R. +6.26 hühnereigrop 眼球突出 $(+)$ Graef $(+)$ Dalrymple (t) Glanzauge( + ) Tachycardie 121/M

\begin{tabular}{|c|c|c|c|c|}
\hline & 甲 & $\begin{array}{l}92 \mathrm{mg} \\
3 \mathrm{cc} \\
\end{array}$ & 乙 & $\begin{array}{c}83 \mathrm{mg} \\
9 \mathrm{cc}\end{array}$ \\
\hline $2 \sigma_{\mathrm{uhh}}$ & & 8(最大) & 17(最大) & \\
\hline 210 & & 6 & 6 & \\
\hline 215 & & 5 & 7 & \\
\hline 220 & & 6 & 7 & \\
\hline $2^{25}$ & & 5 & 8 & \\
\hline 280 & & 6 & 8 & \\
\hline $2^{85}$ & & 5 & 6 & \\
\hline 240 & & 4 & 8 & \\
\hline $2^{45}$ & & 5 & 6 & \\
\hline 250 & & 6 & 8 & \\
\hline 255 & & 4 & 6 & \\
\hline 30 & & 4 & 7 & \\
\hline & & 66 Qo2...........4.58 & \multicolumn{2}{|c|}{$94 \ldots \ldots \ldots \ldots \ldots \ldots \ldots .66$} \\
\hline 35 & & 6 & 6 & \\
\hline $3^{10}$ & & 4 & 8 & \\
\hline $3^{15}$ & & 7 & 6 & \\
\hline $3^{20}$ & & 4 & 8 & \\
\hline 325 & & 6 & 8 & \\
\hline $3^{80}$ & & 5 & 6 & \\
\hline $3^{355}$ & & 5 & 7 & \\
\hline $3^{4.0}$ & & 5 & 7 & \\
\hline $3^{45}$ & & 6 & 6 & \\
\hline $3^{50}$ & & 5 & 7 & \\
\hline 355 & & 5 & 6 & \\
\hline & & 62 & 81 & \\
\hline
\end{tabular}

Tabelle 8 
Basedow 櫒OSO子 42歳 + 우 $\quad$ B. M. R. +47.69 Hühnereigro $\beta$ 眼球突出 輕度 $(+)$ Möbius( $($ ) Glanzauge( $(t)$ Uberwimpern( + ) Tachycardie 130/M

\begin{tabular}{|c|c|c|c|}
\hline & $\begin{array}{r}101 \mathrm{mg} \\
3 \mathrm{cc} \\
\end{array}$ & \multicolumn{2}{|r|}{$\begin{array}{r}92 \mathrm{mg} \\
9 \mathrm{cc} \\
\end{array}$} \\
\hline $3{ }^{5} \mathrm{uhr}$ & 3 & \multicolumn{2}{|l|}{ 15(最大) } \\
\hline 310 & 7 & \multicolumn{2}{|l|}{4} \\
\hline 315 & 7 & \multicolumn{2}{|l|}{4} \\
\hline 320 & 5 & \multicolumn{2}{|l|}{4} \\
\hline $3^{25}$ & 8(最大) & \multicolumn{2}{|l|}{7} \\
\hline $3^{30}$ & 8 & \multicolumn{2}{|l|}{7} \\
\hline $3^{35}$ & 6 & \multicolumn{2}{|l|}{6} \\
\hline $3^{40}$ & 7 & \multicolumn{2}{|l|}{6} \\
\hline 345 & 7 & \multicolumn{2}{|l|}{4} \\
\hline $3^{50}$ & 7 & \multicolumn{2}{|l|}{7} \\
\hline 355 & 6 & \multicolumn{2}{|l|}{6} \\
\hline 40 & 6. & \multicolumn{2}{|l|}{6} \\
\hline & \multirow{2}{*}{$77 \quad \mathrm{Qo}_{2} \cdots \cdots \cdots \cdots \cdot 3.81$} & \multicolumn{2}{|c|}{$79, \ldots \ldots \ldots \ldots \ldots \ldots, 4,39$} \\
\hline 4.5 & & 6 & \\
\hline 4,10 & 6 & 6 & \\
\hline 415 & 7 & 6 & \\
\hline 420 & 6 & 6 & \\
\hline 425 & 6 & 7 & \\
\hline 430 & 5 & 5 & \\
\hline $4^{35}$ & 6 & 5 & \\
\hline 440 & 6 & 7 & \\
\hline 445 & 7 & 5 & \\
\hline $4^{60}$ & 5 & 4 & \\
\hline $4^{55}$ & 7 & 7 & \\
\hline 50 & 5 & 7 & \\
\hline & 73 & 70 & \\
\hline
\end{tabular}

Tabelle 9

Basedow 島O ひO 27歲 우 $\quad$ B. M. R. +11.24 hühnereigro $\beta$ 眼球突出 輕度 $(+)$ Dalrymple( + ) Graefe( + ) Möbius(-) Tachycardie 108/M

\begin{tabular}{|c|c|c|c|c|}
\hline & $\begin{array}{r}104 \mathrm{mg} \\
3 \mathrm{cc}\end{array}$ & 乙 $\begin{array}{r}115 \mathrm{mg} \\
9 \mathrm{cc}\end{array}$ & 丙 & $\begin{array}{r}104 \mathrm{mg} \\
9 \mathrm{cc} \\
\end{array}$ \\
\hline $2^{15} \mathrm{uhr}$ & 7 & 14(最大) & 10 & \\
\hline 220 & 8 & 10 & 8 & \\
\hline 225 & 9(最大) & 9 & 6 & \\
\hline $2^{30}$ & 7 & 11 & 9 & \\
\hline $2^{85}$ & 7 & 8 & 8 & \\
\hline $2^{40}$ & 8 & 13 & 8 & \\
\hline 248 & 8 & 9 & 7 & \\
\hline $2^{50}$ & 7 & 9 & 9 & \\
\hline $2^{55}$ & 8 & 7 & 8 & \\
\hline மo & 7 & 10 & 8 & \\
\hline 35 & 8 & 10 & 10 & \\
\hline
\end{tabular}




\begin{tabular}{|c|c|c|c|c|}
\hline 31.0 & 7 & & 12 & 8 \\
\hline & 95 & $Q_{0_{2}} \cdots \cdots \cdots \cdots+\ldots, 52$ & $112 \cdots \cdots 5.30$ & $104 \ldots \ldots .7 .71$ \\
\hline $3^{15}$ & 7 & & 9 & 8 \\
\hline $3^{20}$ & 8 & & 11 & 7 \\
\hline $3^{25}$ & 8 & & 9 & 7 \\
\hline $3^{30}$ & 6 & & 7 & 8 \\
\hline $3^{355}$ & 7 & & 7 & 7 \\
\hline 340 & 8 & & 10 & 5 \\
\hline $3^{455}$ & 7 & & 8 & 10 \\
\hline $3^{50}$ & 6 & & 12 & 7 \\
\hline $3^{55}$ & 5 & & 8 & 7 \\
\hline 40 & 9 & & 10 & 9 \\
\hline 45 & 7 & & 12 & 6 \\
\hline \multirow[t]{3}{*}{410} & - & & 7 & 8 \\
\hline & 105 & & 10 & $\overline{94}$ \\
\hline & & & 117 & \\
\hline
\end{tabular}

Tabelle 10

Basedow 跸O $\mathrm{r} O 24$ 歲 우 $\quad$ B. M, R. +12.54 Ganzeeigro $\beta$ 眼球突出 $(+)$

Dalymple(t) Glanzauge( $(+)$ Uberwimpern( + ) Tacbycardie 138/M

\begin{tabular}{|c|c|c|c|c|}
\hline & $\begin{array}{r}83 \mathrm{mg} \\
3 \mathrm{cc} \\
\end{array}$ & 乙 $\begin{array}{r}72 \mathrm{mg} \\
9 \mathrm{cc}\end{array}$ & 两 & $\begin{array}{r}67 \mathrm{mg} \\
9 \mathrm{cc} \\
\end{array}$ \\
\hline $1^{45}$ uhr & 7 & 13(最大) & 15 & $20 \mathrm{r} \% \mathrm{JK}$ 添加 \\
\hline 150 & 8 & 9 & 6 & \\
\hline 155 & 8 & 7 & 4 & \\
\hline $2^{0}$ & 8 & 5 & 7 & \\
\hline $2^{5}$ & 6 & 10 & 5 & \\
\hline 210 & 9(最大) & 12 & 4 & \\
\hline 215 & 9 & 5 & 7 & \\
\hline 220 & 6 & 6 & 3 & \\
\hline $2^{25}$ & 9 & 13 & 6 & \\
\hline $2^{30}$ & 8 & 7 & 4 & \\
\hline $2^{85}$ & 8 & 11 & 7 & \\
\hline \multirow[t]{2}{*}{$2^{40}$} & 8 & 8 & 5 & \\
\hline & $94 \quad Q_{0} \cdots \cdots \cdots \cdots .66$ & $103 \ldots \ldots 7.15$ & & 4..........5.52 \\
\hline $2^{45}$ & 6 & 9 & 5 & \\
\hline $2^{50}$ & 8 & 8 & 5 & \\
\hline $2^{55}$ & 7 & 6 & 5 & \\
\hline 30 & 7 & 7. & 4 & \\
\hline 35 & 8 & 12 & 4 & \\
\hline 310 & 7 & 4 & 4 & \\
\hline 315 & 8 & 10 & 6 & \\
\hline $3^{20}$ & 6 & 6 & 5 & \\
\hline $3^{25}$ & 7 & 8 & 5 & \\
\hline $3^{30}$ & 9 & - & 4 & \\
\hline $3^{35}$ & 7 & - & 5 & \\
\hline \multirow[t]{2}{*}{$3^{40}$} & - & $100 \cdots \cdots .7 .10$ & - & \\
\hline & $93 \cdots \cdots \cdots \cdots \cdots \cdots .64$ & & & $\overline{7} \cdots \cdots \cdots \cdot \ldots, 25$ \\
\hline
\end{tabular}


Tabell 11

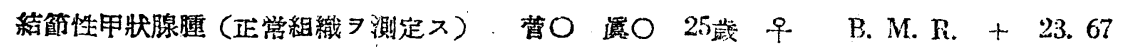
Uberhüherreigro $\beta$ 眼症狀( $($ ) Tachycardi( - )

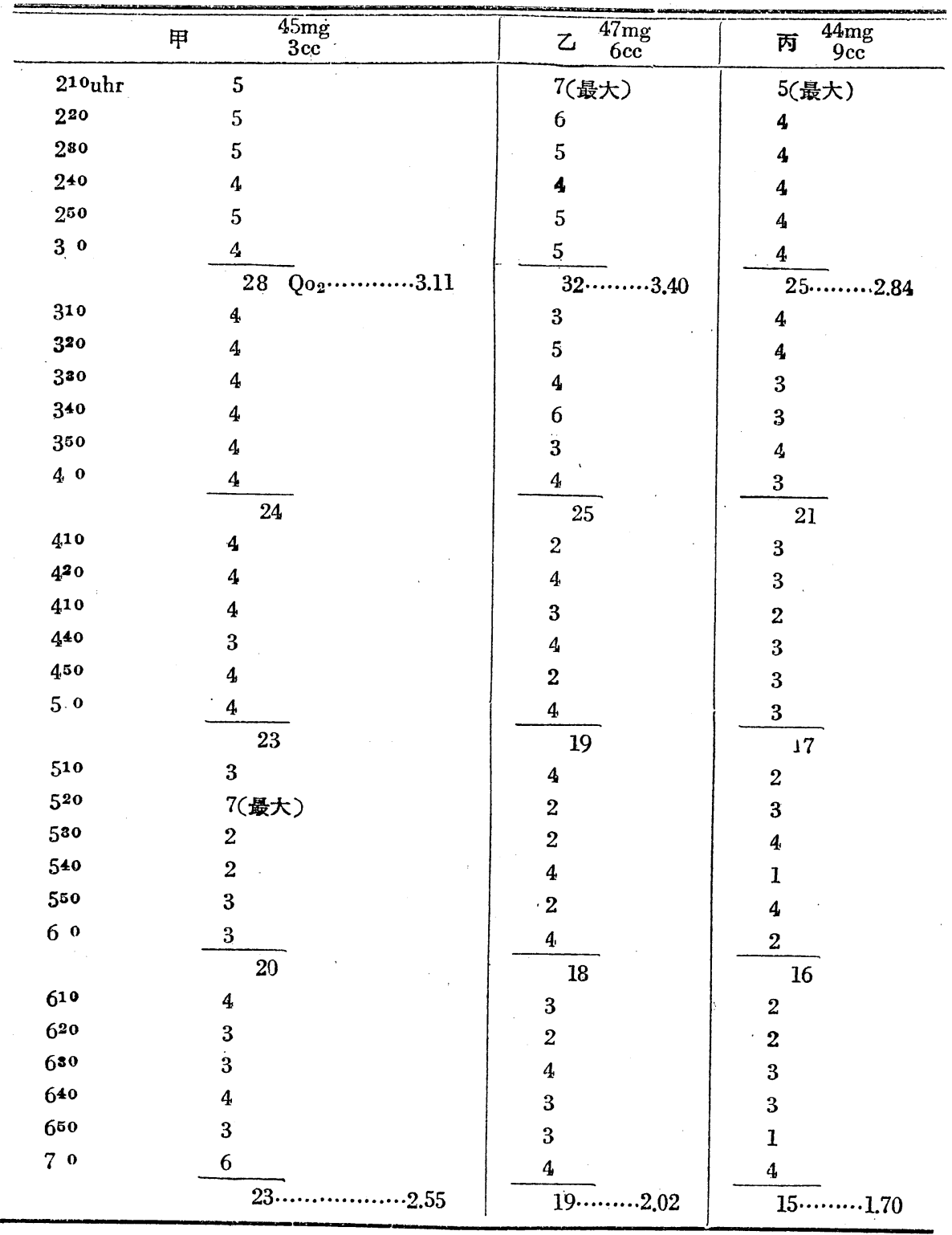

Tachycartie 12

結凔性甲狀腺嗹 (正常租樴) 日OとOの 40 歲 Tachycardie ( - ) 眼球突出( - ) 


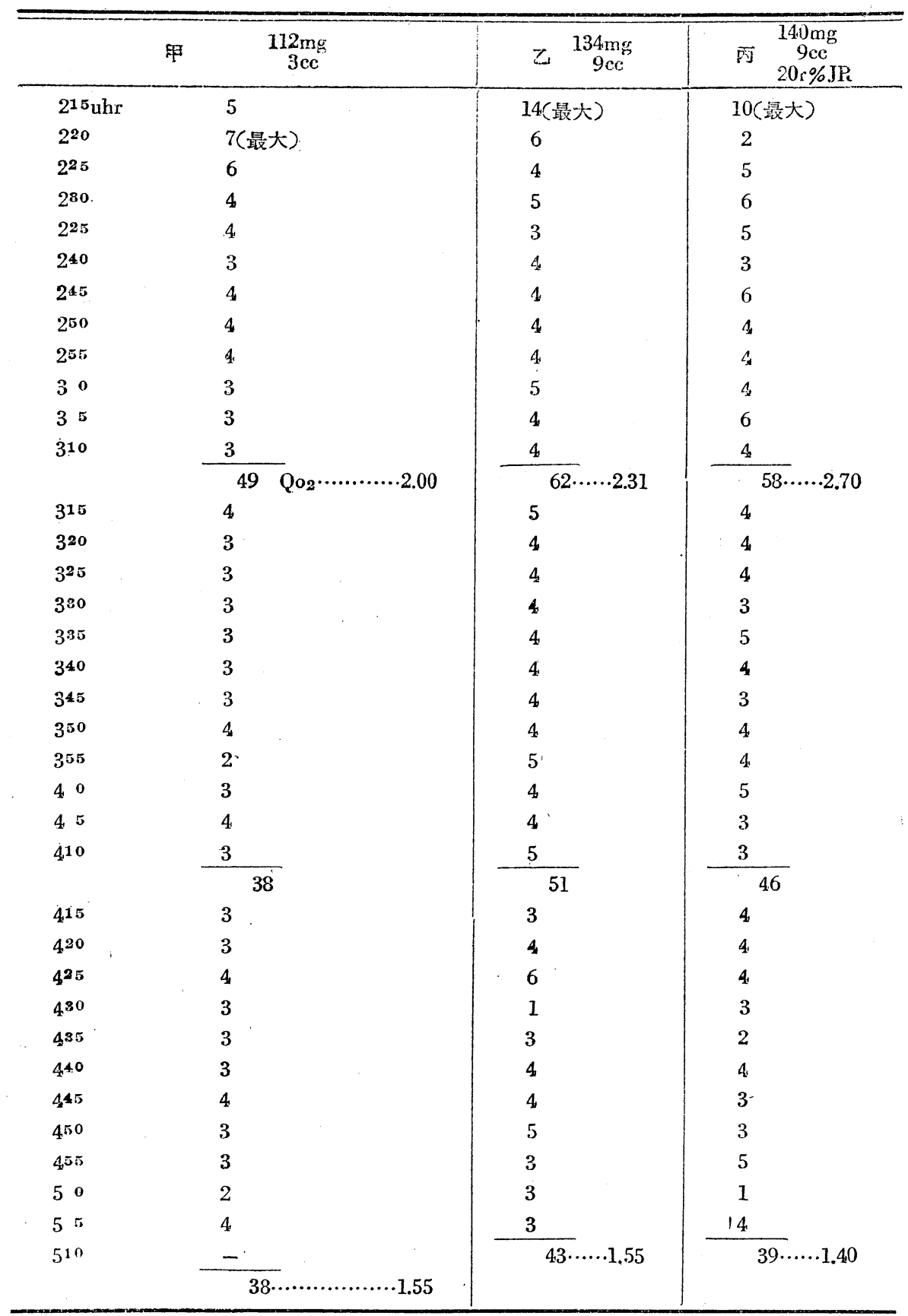

Tabclle 13

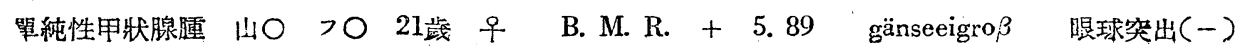
rachycardie $(-)$

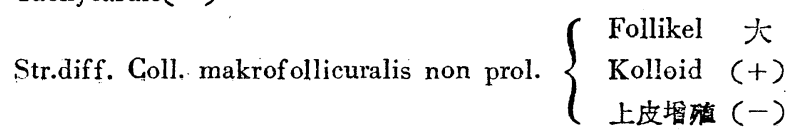




\begin{tabular}{|c|c|c|c|}
\hline \multicolumn{2}{|c|}{ 甲 $\quad 5 \operatorname{lmg}$} & \multicolumn{2}{|c|}{$\begin{array}{cc}\text { 乙 } & 53 \mathrm{mg} \\
5 \mathrm{cc}\end{array}$} \\
\hline $2 \mathrm{ouhr}^{\mathrm{u}}$ & 5 & 3 & \\
\hline 210 & 5 & 7 (最大) & \\
\hline 220 & 6 & 5 & \\
\hline 230 & 4 & 3 & \\
\hline 240 & 3 & 4 & \\
\hline \multirow[t]{2}{*}{$2^{50}$} & 5 & 7 & \\
\hline & 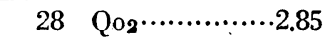 & $29 .$. & …........2.84 \\
\hline 30 & 5 & 5 & \\
\hline 310 & 7(最大) & 2 & \\
\hline 320 & 2 & 7 & \\
\hline 330 & 3 & 2 & \\
\hline $8^{40}$ & 4 & 4 & \\
\hline $3^{50}$ & 4 & 4 & \\
\hline & 24 & 26 & \\
\hline
\end{tabular}

\section{Tabelle 14} Str. diff coll. basedowificata $\left\{\begin{array}{l}\text { Follikel 大 } \\ \text { Kolloid }+ \\ \text { 上皮增殖 }(-)\end{array}\right.$ 甲狀腺中毒症 石○ま○と 43 践 早 B.M.R. + 28. 88 Gänseeigro $\beta$ 眼症狀 $(-)$ Tachycardie 109/M

\begin{tabular}{|c|c|c|c|}
\hline & $\begin{array}{c}82 \mathrm{mg} \\
5 \mathrm{cc}\end{array}$ & 乙 $\begin{array}{c}77 \mathrm{mg} \\
5 \mathrm{cc}\end{array}$ & 丙 $\begin{array}{c}96 \mathrm{mg} \\
5 \mathrm{cc}\end{array}$ \\
\hline $230 \mathrm{uhr}$ & 9 & 10 & - \\
\hline 240 & 18(最大) & 12 & - \\
\hline $2^{50}$ & 15 & 17(最大) & - \\
\hline 30 & 12 & 13 & - \\
\hline 310 & 9 & 8 & - \\
\hline 320 & 15 & 13 & - \\
\hline & $73 \quad \mathrm{Qo}_{2} \cdots \cdots \cdots \cdots \cdots \cdot 60$ & $75 \cdots \cdots 4.82$ & \multirow{15}{*}{$\overline{69} \ldots \ldots .3 .55$} \\
\hline $3^{30}$ & 13 & 11 & \\
\hline $3^{40}$ & 11 & 11 & \\
\hline $3^{50}$ & 17 & 10 & \\
\hline 40 & 13 & 12 & \\
\hline 410 & 11 & 13 & \\
\hline 420 & 8 & 13 & \\
\hline & 62 & 69 & \\
\hline 430 & 10 & 11 & \\
\hline 440 & 10 & 7 & \\
\hline 450 & 11 & 9 & \\
\hline 50 & 9 & 13 & \\
\hline 510 & 8 & 11 & \\
\hline \multirow[t]{2}{*}{520} & 10 & 6 & \\
\hline & 57 & 62 & \\
\hline
\end{tabular}

Tabelle 15

甲状腺中毒症 木O 信O 20 䈅 우 B. M. R. +52.24 Gäuseeigro $\beta$ 右眼球突出 $(+)$ Möbins $(+)$ GIanzauge( $(+)$

Str. diff. eoll. mac. prol. $\begin{cases}\text { Follikol } & \text { 大 } \\ \text { Colloid } & ( \pm)\end{cases}$ 
Uberwimpern $(+)$ Tachycardie $114 / \mathrm{M}$

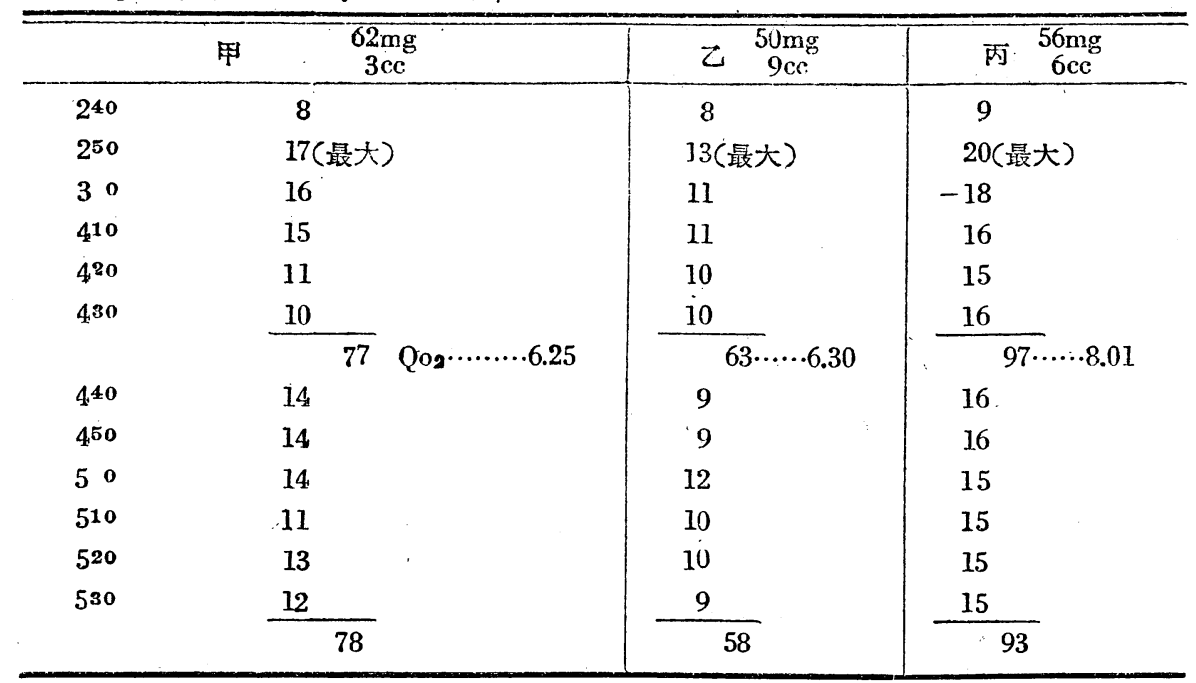

Tabelle 16

甲狀腺中毒症 佐O 愛O 19歲 우

B. M. R. +24.82 Unterhühnereigro $\beta$ 眼症狀(一) Tachycardie $9.7 / \mathrm{M}$

\begin{tabular}{|c|c|c|c|c|}
\hline . & 甲 & $\begin{array}{c}112 \mathrm{mg} \\
3 \mathrm{cc}\end{array}$ & 乙 $\begin{array}{c}134 \mathrm{mg} \\
9 \mathrm{cc}\end{array}$ & 丙 $\begin{array}{c}107 \mathrm{mg} \\
6 \mathrm{cc}\end{array}$ \\
\hline $2^{15}$ uhr & & 8 & 11 & 6 \\
\hline $2^{20}$ & & 11(最大) & 12(最大) & 5 \\
\hline $2^{25}$ & & 7 & 6 & 6 \\
\hline $2^{30}$ & & 6 & 5 & 5 \\
\hline 235 & & 5 & 6 & 6 \\
\hline $2^{40}$ & & 6 & 7 & 5 \\
\hline 245 & & 5 & 5 & 5 \\
\hline $2^{50}$ & & 5 & 5 & 5 \\
\hline 255 & & $\dot{5}$ & 6 & 5 \\
\hline 30 & & 6 & 5 & 6 \\
\hline 35 & & 4 & 6 & 4 \\
\hline \multirow[t]{2}{*}{310} & & 5 & 5 & 6 \\
\hline & & 78 Qo 2 ........2.94 & $\overline{79} \cdots \ldots .2 .94$ & $\overline{64} \cdots \cdots 2.78$ \\
\hline $3^{15}$ & & 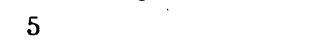 & 6 & 4 \\
\hline $3^{20}$ & & 4 & 5 & 5 \\
\hline $3^{25}$ & & 5 & 6 & 5 \\
\hline $3^{30}$ & & 5 & 7 & 5 \\
\hline $3^{85}$ & & 6 & 5 & 5 \\
\hline $3^{40}$ & & 5 & 5 & 4 \\
\hline $3^{45}$ & & 5 & 6 & 6 \\
\hline $3^{50}$ & & 5 & 4 & 4 \\
\hline $3^{55}$ & & 5 & 6 & 5 \\
\hline 40 & & 4 & 6 & 4 \\
\hline 45 & & 4 & 6 & 4 \\
\hline \multirow[t]{2}{*}{410} & & 7 & 5 & 4 \\
\hline & & 61 & 67 & 55 \\
\hline
\end{tabular}


Tabelle 17

甲狀腺中复症. 佐O 2030 瓷 + ㅇ $\quad$ B. M. R. + 1.84 Gänseeigro $\beta$ 眼球突出(一) Glanzauge $(t)$ Tachycardie $100 / \mathrm{M}$

\begin{tabular}{|c|c|c|c|c|}
\hline & 甲。 & $\begin{array}{c}112 \mathrm{mg} \\
6 \mathrm{cc}\end{array}$ & 乙 & $\begin{array}{c}81 \mathrm{mg} \\
9 \mathrm{cc}\end{array}$ \\
\hline $210 \mathrm{uhr}$ & & 10 & 14(最大) & \\
\hline $2^{15}$ & & 16 & 10 & \\
\hline $2^{20}$ & & 18(最大) & 12 & \\
\hline $2^{25}$ & & 18 & 12 & \\
\hline $2^{30}$ & & 18 & 12 & \\
\hline $2^{85}$ & & 12 & 8 & \\
\hline 240 & & 16 & 8 & \\
\hline 245 & & 16 & 12 & \\
\hline 250 & & 14 & 10 & \\
\hline 255 & & 14 & 10 & \\
\hline 30 & & 10 & 10 & \\
\hline \multirow[t]{2}{*}{35} & & 14 & 6 & \\
\hline & 89 & 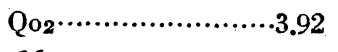 & $66 \ldots \ldots$ & ............4.07 \\
\hline 310 & & 16 & 14 & \\
\hline 315 & & 10 & 6 & \\
\hline 320 & & 12 & 6 & \\
\hline 325 & & 10 & 10 & \\
\hline
\end{tabular}

Tabelle 18

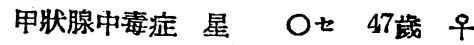

Möbius( $($ ) Graefe( + ) Tachycardie( - )

\begin{tabular}{|c|c|c|c|}
\hline & $\underset{3 \mathrm{cc}}{115 \mathrm{mg}}$ & 乙 $\begin{array}{c}70 \mathrm{mg} \\
9 \mathrm{cc}\end{array}$ & 丙 $\begin{array}{c}108 \mathrm{mg} \\
9 \mathrm{cc} \\
20 \mathrm{r} \% \mathrm{KJ}\end{array}$ \\
\hline 25 uhr & 9 & 10（最大) & 13(最大) \\
\hline 210 & 10(最大) & 9 & 10 \\
\hline 215 & 10 & 10 & 10 \\
\hline 220 & 9 & 7 & 13 \\
\hline 225 & 9 & 6 & 8 \\
\hline 230 & 7 & 8 & 10 \\
\hline 235 & 7 & 5 & 8 \\
\hline $2^{40}$ & 8 & 7 & 9 \\
\hline 245 & 6 & 7 & 7 \\
\hline 250 & 7 & 5 & 9 \\
\hline $2^{55}$ & 7 & 6 & 8 \\
\hline 20 & 6 & 6 & 8 \\
\hline & 85 Qoa $\cdots \cdots \cdots \cdots . . .64$ & $83 \cdots . .5 .90$ & $123 \cdots . .5 .69$ \\
\hline 35 & 7 & 6 & 8 \\
\hline 310 & 7 & 6 & 8 \\
\hline 315 & 6 & 5 & 7 \\
\hline $3^{20}$ & 6 & 6 & 9 \\
\hline $3^{25}$ & 7 & 6 & 7 \\
\hline 330 & 7 & 6 & 9 \\
\hline
\end{tabular}




\begin{tabular}{ll|l|l}
\hline $3^{35}$ & 7 & 5 & 7 \\
$3^{40}$ & 6 & 6 & 8 \\
$3^{45}$ & 7 & 6 & 7 \\
$3^{50}$ & 6 & 5 & 8 \\
$3^{55}$ & 6 & 5 & 7 \\
40 & 6 & 6 & 7 \\
\hline
\end{tabular}

\section{Tabelle 19}

甲狀腺中症 村O 和O 19 合 $\quad$ B. M. R. +2.30 Hühnereigro $\beta$

Tachycardie 98/M 眼症狀( 一) 雨上眼瞼 =祳類アリ

\begin{tabular}{|c|c|c|c|}
\hline & $\begin{array}{c}112 \mathrm{mg} \\
3 \mathrm{cc}\end{array}$ & 乙 & $\begin{array}{c}99 \mathrm{mg} \\
6 \mathrm{cc}\end{array}$ \\
\hline $210 \mathrm{uhr}$ & 5 (樶大) & \multicolumn{2}{|l|}{3} \\
\hline 215 & 3 & \multicolumn{2}{|l|}{3} \\
\hline $2^{20}$ & $?$ & \multicolumn{2}{|l|}{3} \\
\hline $2^{25}$ & 4 & \multicolumn{2}{|l|}{2} \\
\hline $2^{30}$ & 2 & \multicolumn{2}{|l|}{4 (最大) } \\
\hline $2^{35}$ & 3 & \multicolumn{2}{|l|}{2} \\
\hline $2^{40}$ & 3 & \multicolumn{2}{|l|}{2} \\
\hline 245 & 3 & \multicolumn{2}{|l|}{2} \\
\hline 250 & 3 & \multicolumn{2}{|l|}{3} \\
\hline 255 & 2 & \multicolumn{2}{|l|}{2} \\
\hline 30 & 3 & \multicolumn{2}{|l|}{3} \\
\hline 35 & 2 & \multicolumn{2}{|c|}{2} \\
\hline & $\overline{\mathrm{Qo}_{2}} \cdots \cdots \cdots \cdots \cdots \cdots \cdots \cdots \cdots \cdots \cdots$ & \multicolumn{2}{|c|}{ 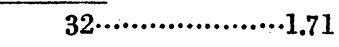 } \\
\hline 310 & 3 & 1 & \\
\hline 315 & 2 & 2 & \\
\hline $3^{20}$ & 3 & 2 & \\
\hline $3^{25}$ & 2 & 2 & \\
\hline $3^{30}$ & 3 & 3 & \\
\hline $3^{85}$ & 2 & 2 & \\
\hline 340 & 2 & 1 & \\
\hline 345 & 2 & 3 & \\
\hline 350 & 2 & 1 & \\
\hline 355 & 3 & 2 & \\
\hline 40 & 3 & 2 & \\
\hline 45 & 3 & 2 & \\
\hline & 30 & 23 & \\
\hline
\end{tabular}

Tubelle 20

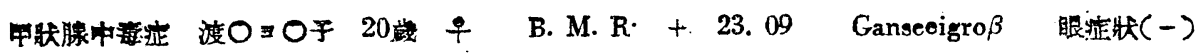

Tachycardie $123 / \mathrm{M}$ 


\begin{tabular}{|c|c|c|c|c|}
\hline & $\begin{array}{c}43 \mathrm{mg} \\
3 \mathrm{cc} \\
\end{array}$ & $\begin{array}{lr}\begin{array}{r}42 \mathrm{mg} \\
9 \mathrm{cc}\end{array} \\
\end{array}$ & 丙 & $\begin{array}{l}45 \mathrm{mg} \\
6 \mathrm{cc}\end{array}$ \\
\hline $215 \mathrm{uhr}$ & 3 & 7(最大) & 4 & \\
\hline $2^{20}$ & 5 & 6 & 4 & \\
\hline 225 & 3 & 3 & 3 & \\
\hline $2^{80}$ & 5 & 4 & 4 & \\
\hline $3^{85}$ & 4 & 5 & 5 & \\
\hline 340 & 5 & 4 & 4 & \\
\hline $3^{45}$ & 5 & 4 & 4 & \\
\hline 350 & 6(最大) & 7 & 12 & \\
\hline 355 & 3 & 4 & 4 & \\
\hline 40 & 3 & 5 & 5 & \\
\hline 45 & 4 & 3 & 3 & \\
\hline \multirow[t]{2}{*}{410} & 5 & 5 & 4 & \\
\hline & $51 \quad \mathrm{Qo}_{2} \ldots \ldots \ldots \ldots . .93$ & $57 \ldots \ldots .6 .79$ & & $9 \ldots \ldots .5 .56$ \\
\hline 415 & 3 & 3 & 3 & \\
\hline 420 & 4 & 2 & 5 & \\
\hline
\end{tabular}

曲 線

Basedow 村 $\bigcirc$ と $\bigcirc$ 38蛓 \& Tabelle5

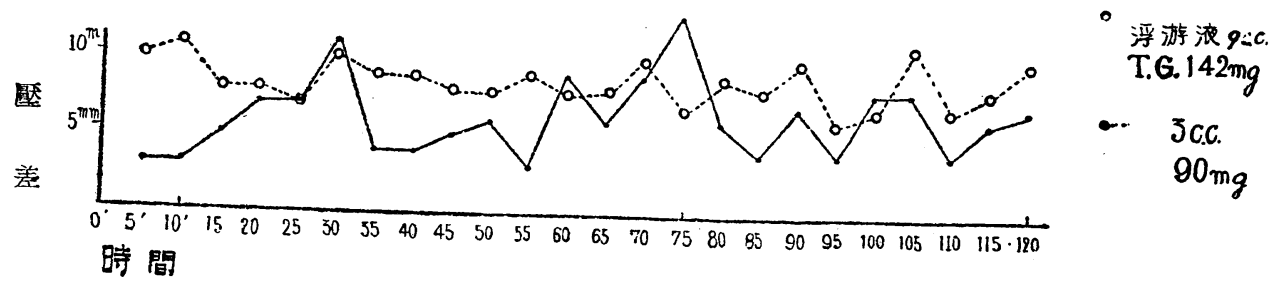

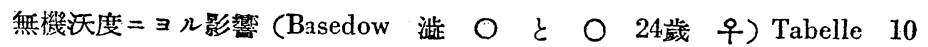

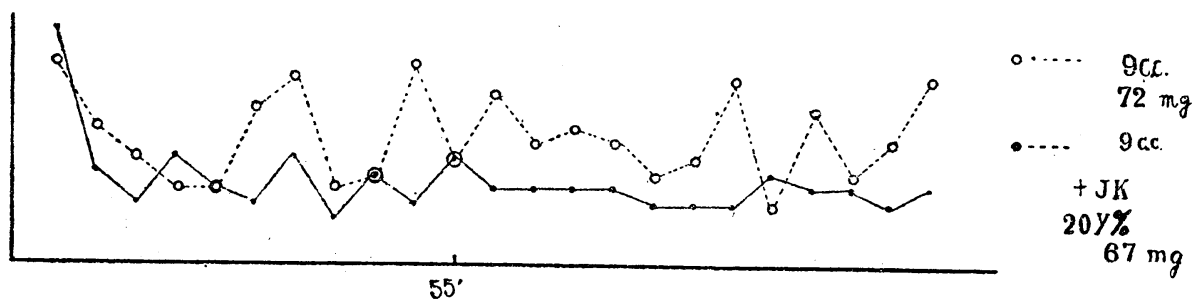

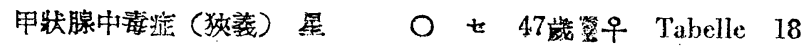

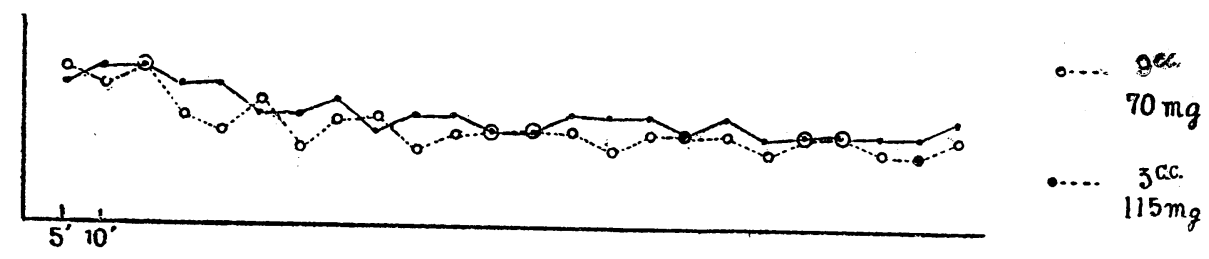


結節性甲狀腺腫 (正常組幽甲測定ス) 日 $○$ と の 40 歲 ㅇ Tabelle 12

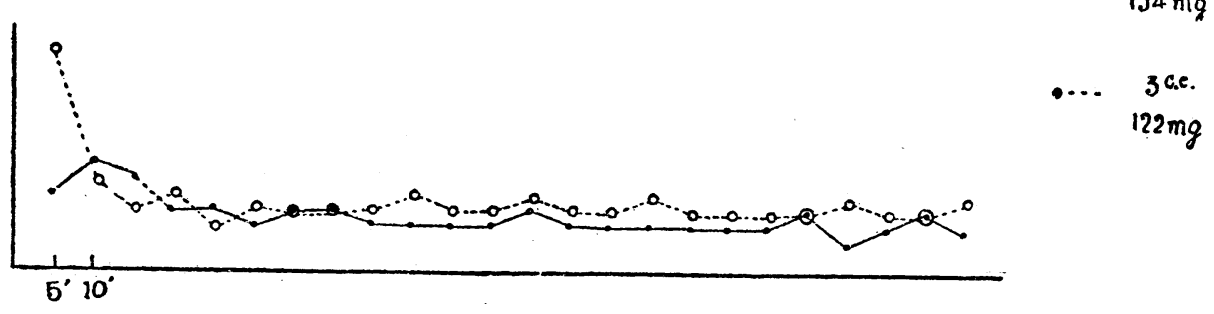

第 2 節 呼吸型ニツイテ

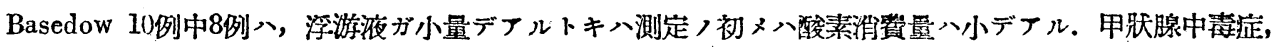
ソ，他ハ小デナイ． 然シ Basedow，呼吸型デ初メガ小デフッテモ時間フ經過卜共二次第二增大スル， 120

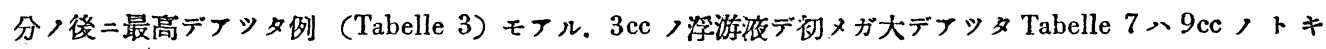

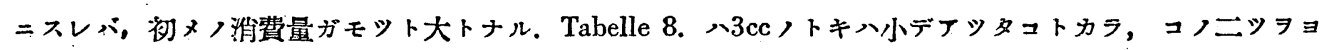

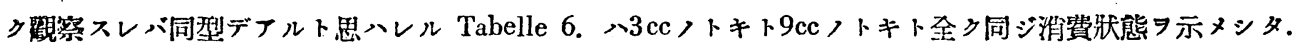
故ニコノ例>例外トスル。

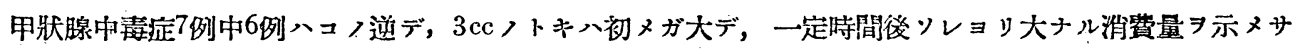

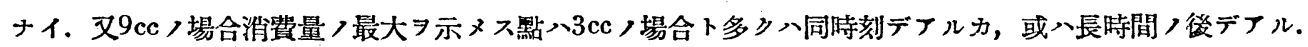
コレニ反シテ Bssedow >9cc 場合八3cc/最大シ示メス點ヨり短時間デノル。

甲爿腺中毒1例、Basedow，呼吸型デフル(Tabelle 20).

單純性甲狀腺腫1例、(Tabclle 13) 被檢材料卜浮游夜下, 比ガ不適當デアッタ.

正常甲狀腺組織2例 (Tabelle 11. 12) 入3ccトキ，呼吸型二動摇习ミセナカッタ.ソノ他入皆動摇习示

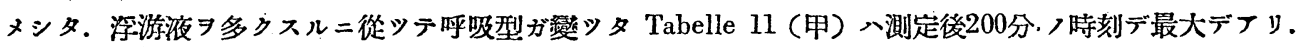

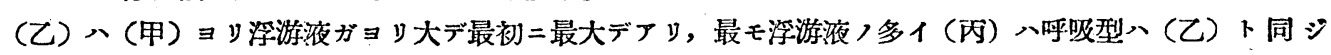

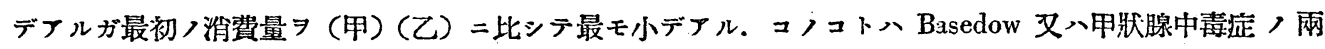
型二移行スル可能性 $タ$ 示メス.

1例デアルガ (Tabelle 10) $20 \mathrm{Y} \%$ 拜機沃度 他 フ3例ニッイテ沃度 / 作用

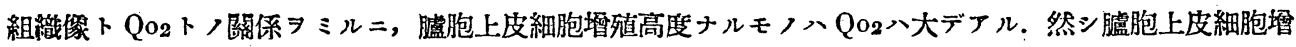

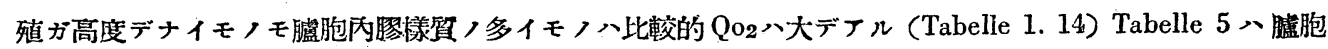

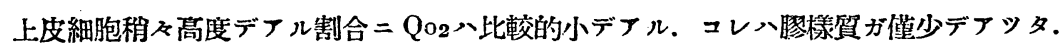

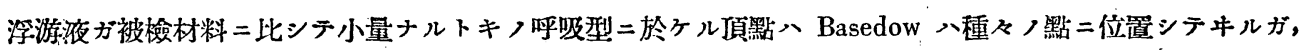

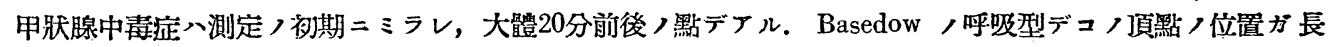

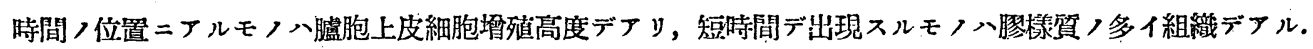

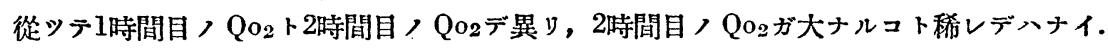

Q02 r基碟代謝率ノ關倸八特定ノモノハナクQ02ガ大デモ基碟代謝率ハ小，コノ逆モアル。

\section{第 4 章考按}

Hormann. Paal 3) - Warburg >法二從飞浮游液血清デらつて, 甲壯腺二, Thyroxin, Thyreotropes Hor-

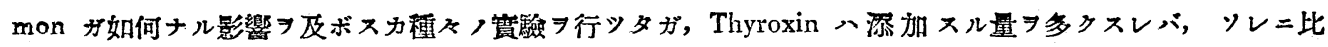

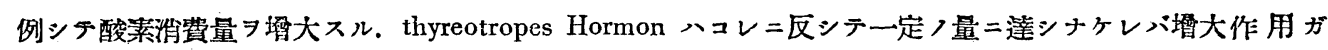
現ハレナイ. Thyroxin 八酸素消費量〉低下率シ大ナラシヌルガ, Tyreotropes Hormon ハ小デアル. thy-

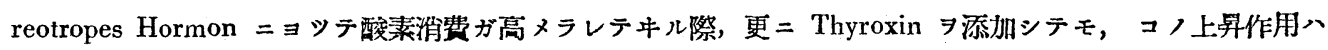




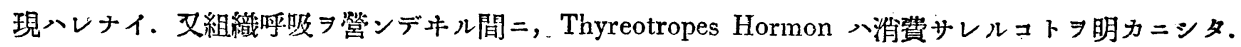

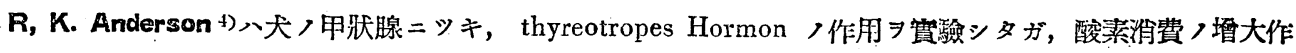
用八時間ガ經過スルニ從ツテ大トナルコトラ明カニシタ. 郎于1時間ヨリ3時間目ガオソレカラ次第二低下ス 几.

1948 > Leblond \& Gross S)八 thyreotropes Hormon /注射八甲狀腺〉䐦胞上皮二於テ, Thyreoglobulin

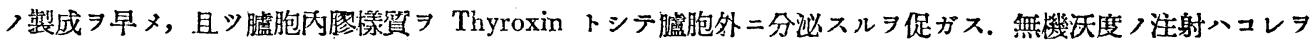
阻止スルト．腦下垂體除去モ阻止スルトらつて二於テ實驗シタ。

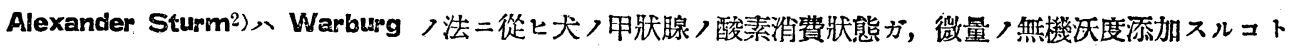

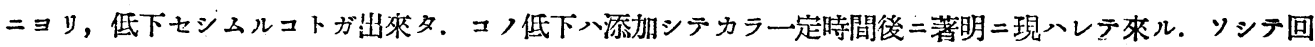

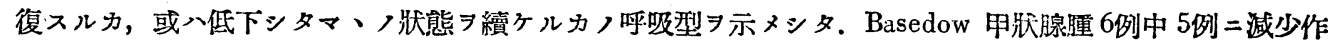
用 $\ni$, 單純性甲跃腺腫4例中1例 $=$ 認メタ. (浮游液, 血清, 無機沃度, $5 r$ Jod pro ccm).

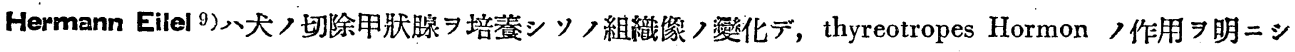

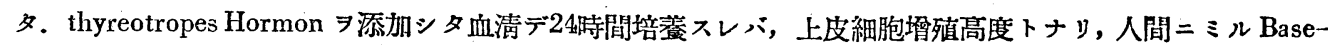

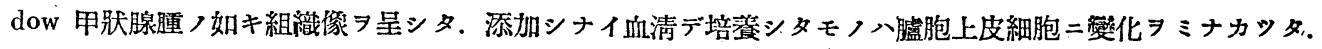
又臚胞內膠羕質二關シテハ, tnyreotropes Hormon，淙加セル方ハ消失シデタ.コ、デュ，Hormon，

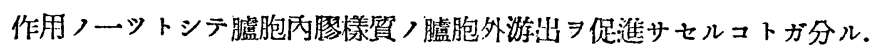

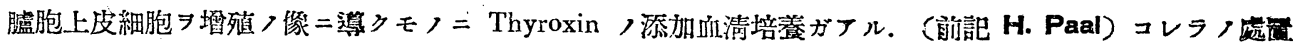

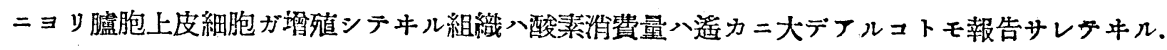

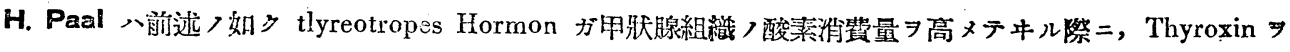
源加シテェコノ作用入現ハレナイトイフ虎カラ, thyreotropes Hormon ト Thyroxin ト八拮抗作用ガフルダ

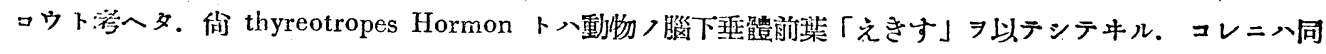

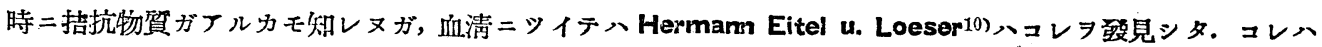
種特異性ガナイ. 叉同種屬ニシイテモソノ强サ二差翼ガアル.

サテ余ノBasedow，呼吸型デ，最初三消費量ガ低ク，時間ノ經過卜共二高クナル場合习帣へル二, 酸素 消費量习高メル thyreotropes Hormon (邓、Thyroxin) =拮抗スル antithyreotropes Hormon / 存在 $习$ 洘

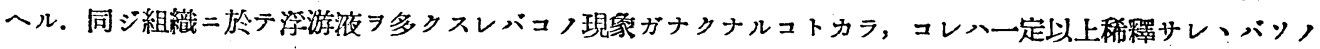

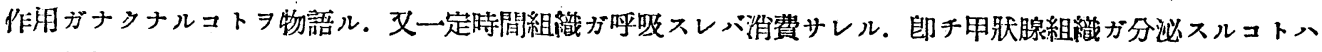

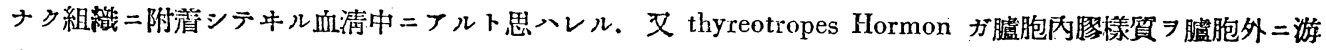
讪スルコトジ促淮サセ, antithyreotropes Hormon ガ游出ヨ阻止スルト考へレバ便利デナル. Basedow ガ thyreotropes Hormon >作用ヨy antithyreotropes Hormon ガ影著ナリトスレパ, 甲頂腺中毒症ハコノ逆, 正常組織八兩作用ガ均等デンル.

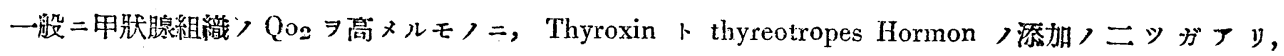
Prolar. Hypophysin. A-Vitamin. Follikulin ハコ/作用ガナイ (H. Paal). Suprarenin, Insulin ハコノ作 用ガナイ (炭Alexander Sturm).

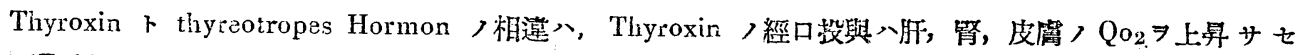

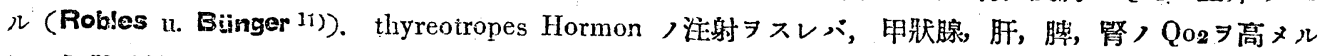

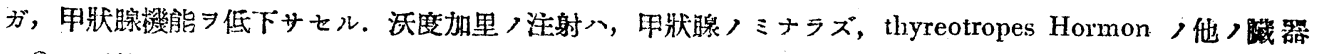

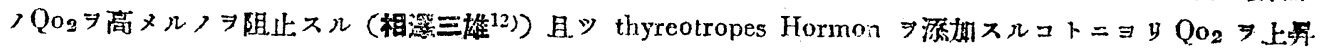
シ得儿組織ハ, 甲壯眿ダケデフル(R. K, Anderson \& Howard).

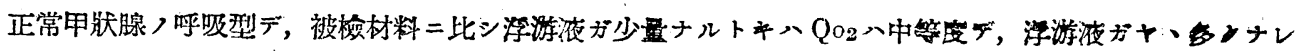

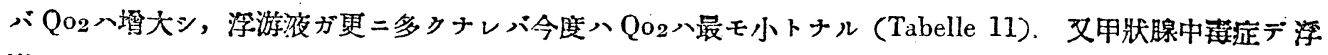

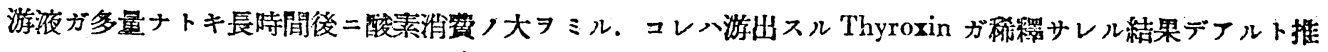

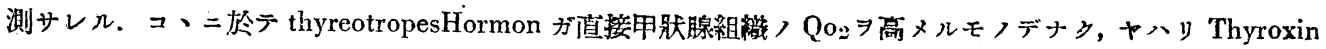
デフルト赖ヘラレル。 


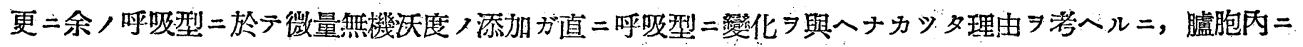

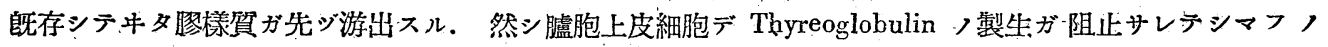
デ, 臚胞內二賿樣質ガナタナル。故二一定時間ガ經過シタ後動摇ヨミヌ呼吸型トナツタト考ヘラレル． A.

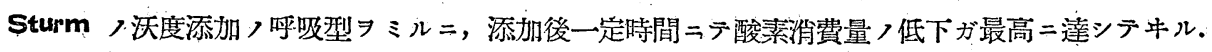

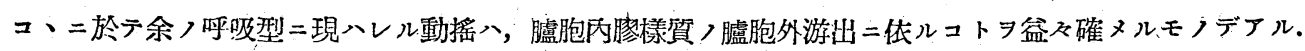
卜同時二甲狀腺= di-Jodtyrosin : ガタクワヘラレルノヨ阻止スルガ, Woiff. IL. Chalkoff 13)), 既存セル di-Jodtyrosin カラ Thyroxin =變化スルコトニ八無關係デアルロトガ暗示サレル:

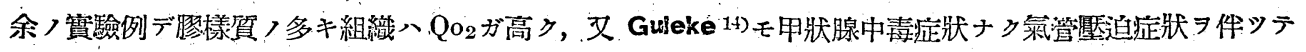

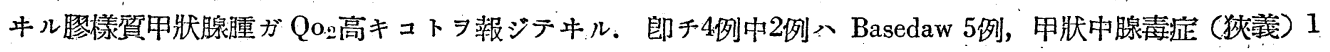

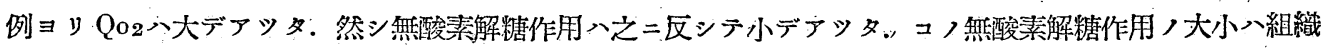

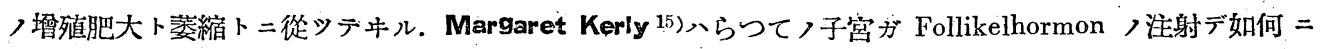

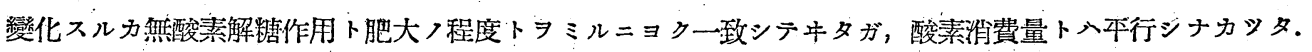
前記 H. Paal モ Thyroxin $=\Xi y$ 甲狀腺組織ノ無酸素解糖作用ガ如何二變化スルカシラベタガ, 添加せザ ル場合ヨリ遥カ二大デアッタ. thyreotropes Hormon >添加ノ場合八添加セザル場合卜大差ガナカッタ.

A. Sturm モ無機沃度デ酸素消費八低下スルガ，之二反シテ無酸素解糖作用八增大シタ. 即于最モ低下シタ 酸素消費 ツタ.

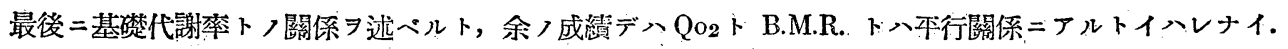
Robles 及ビ Bünger 11)八動物二 Thyroxin ヨ經口的二與へルト先ジ B.M.R. ガ上昇习始メル. シカシリ

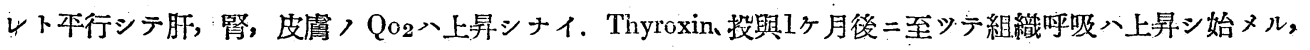
コノコトハ神經系統ガ間接二影響シテキルコトヨ想化サセルトイッタ. Victer ト Anderson 16)八らつてヨ

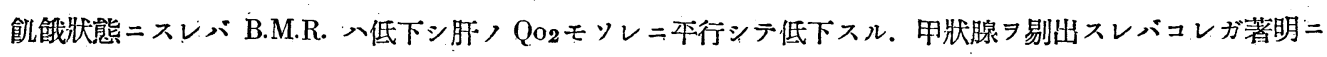

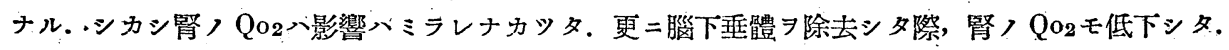

故= B.M.R. ヨ元進セシムルモノ八甲狀腺ノミガ關倸シテ年ルトハイハレナイ.

\section{第 5 章 總括}

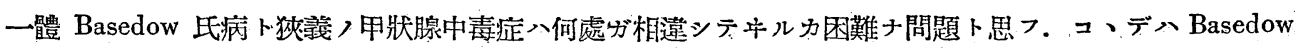
トハ定型的「ばせどう」ヨ゙云と，眼症狀特二眼球笑出

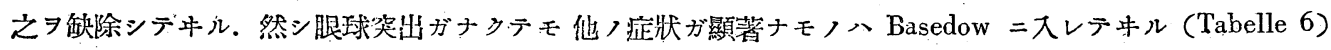
コノ症例入余ノ呼吸型ヨリミレバ甲狀腺中毒症二大レタ方ガョ・イト思ハレル，又 Tabelle 15，八右眼球哭 出ガアリ，ソノ他ノ腿淀狀 八甲狀腺中毒症>呼吸型デアル. Tabelle 20, 公眼球突出ソ, 他〉眼症狀ガナク診斷入甲狀腺中毒症デ アッ

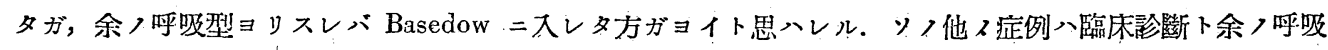

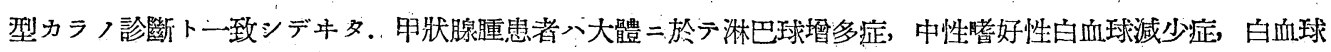
減少症 織像ノ墂殖程度, ソノ他二体ツテモ區別スルニ至ツティナイ。

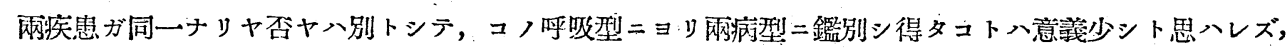
コ、ニ報告シタ次第デアル。

\section{第 6 音 結論}

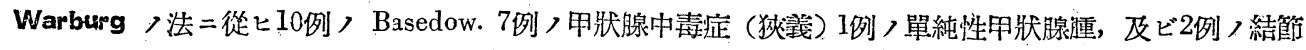
性甲狀腺腫 (正常組織) ニッイテ, 酸素消費狀態 觀察シ, 次ノコトヨ明カーシタ.

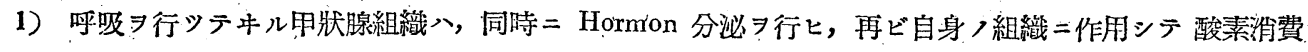
ヨ高メル。 


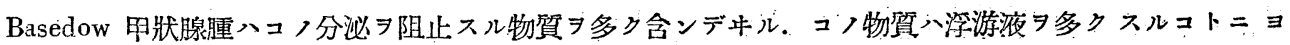
リ，ソノ作用ガ减少スル。文組織ガ呼吸ヨ營ンデキル間二消費サレル。

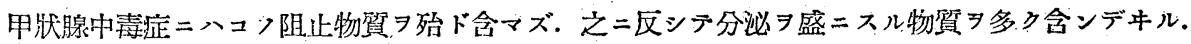

正常ナル甲狀腺組織入雨物賀

2）酸素渻費量八臚胞上皮細胞ノ堙殖高度ナルモノ程大デアルガ，又臚胞內膠樣賀ノ含有量ノ大ナルモノ 程大デアル.

浮游液ガ血清デナイトキ，浮游液卜被檢材料ノ量ノ比二依ツテ呼吸係數ガ異ル。

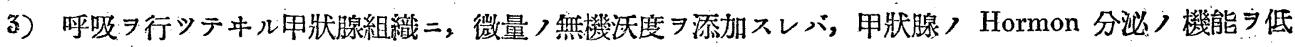

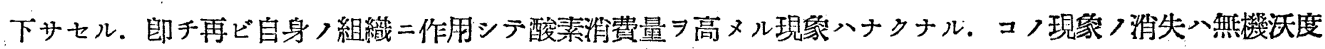
添加後值二現ハレルモノデハナク，一定時間习經過シタ後二現ハレル.

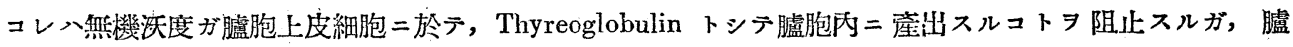
胞內膠樣賀 7 Thyroxin トシテ臚胞外二游出スルコトニハ何ラ關與シナイコトラ䕎示スル.

4) 甲狀腺組織, 呼吸係數 Q $0_{2}$ 卜基碟代謝率卜二特定ノ關係ハミラレナイ. 基礎代謝率ヨ高メルモノフ, 甲狀腺機能元進三ノミ求メルコトハ出來ナイ.

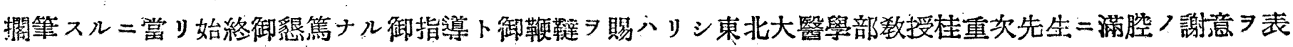
ス.

\section{文献}

1) Von G. Borger Krh forschung 7: 104-118' 29.

2) Alexander Sturm Ztschr. f. d. $74: 555.574$ ' '30.

3) Hermann Paal Klin. Wschr. 12.1. 615 '33.

4) R. K. Anderson \& Horward Amer. Jour. of. Physiol 19 '37.

5) Dixon H. A. Manometric Method 71.'34.

6) Negelein. Warburg. Posener Bioch. Z. 152. 309. 1924.

7.) Negelein

8) Leblond u Gross End. Nov. 306 '48.

9) Hermann Eitci Klin. Wschr. 12.1. 6151933.

10) Hermann Eitel u Loeser Klin. Wschr. 1742 '34,

11) Robles u Bünger Frankf. Z. Path. 41. 1931 '31.

12）相摆三雄. 日內分泌. 15卷上. 昭14. 396頁.

13) Wolff IL. Chalkoff, End. Sept. 148.

14) Guleke Ztschr. f. d. 74: 555-574, '30.

15) Margaret Kerly Bioch. Jour. 31: 1544.'37.

16) Victer u Anderson Amer. Jour. Physiol. 122. 296' '38.

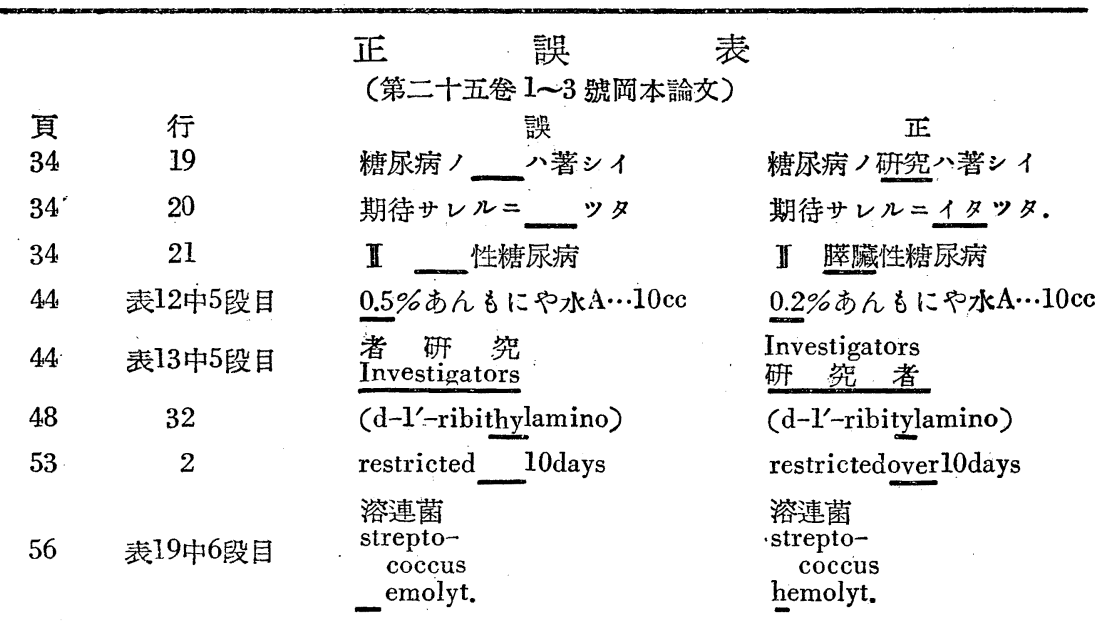

第 25 卷 $4 \sim 6$ 